\title{
Role of Literary Pedagogy in Modern Education of Preschool and Primary School Children
}

Elena Mikhailovna Shastina, ${ }^{\dagger}$ Stephanie Jentgens, ${ }^{\neq}$Olga Vasilyevna Shatunova, ${ }^{{ }^{*}}$ Anatoly Mikhailovich Borisov' and Galina Nikolaevna Bozhkova ${ }^{\beta}$

\section{Abstract}

The study examines the concept of literary pedagogy as an integral part of the educational process. The authors argue that literary pedagogy as a modern trend in human development is linked to the system of continuous education, which is implemented in formal, non-formal and informal education. A distinction should be drawn between the concepts of literary education and literary pedagogy. Literary education as a process of an individual's incorporation into the culture by means of literature is generally provided within the framework of formal education and is based on two fundamental principles - artistic and literary-aesthetic. The authors consider literary education as an aspect of literary pedagogy. This research examines the experience of the formation and development of literary pedagogy. Particular attention is given to the issue of training specialists who would be prepared to support children's and youth reading. Given the integrative, interdisciplinary character of the reading skill, the research presents strong evidence in favour of literary pedagogy which is developing as a branch of pedagogy and as a reaction to the fall of interest in reading. Furthermore, the study provides an overview of the literary pedagogy.

Keywords: Literature; Literary Education; Literary Pedagogy; Formal, Non-formal and Informal Education

\footnotetext{
${ }^{+}$Dr. Sci. (Philology), Professor, Head of German Philology Department, Kazan Federal University, Elabuga Institute, Russia, Elabuga

${ }^{*}$ Corresponding Author, Email: olgashat67@mail.ru

${ }^{*}$ Dr. Phil. University Halle-Wittenberg, Germany, Halle (Saale)

i PhD, Associate Professor, Head of Department of Pedagogy, Kazan Federal University, Elabuga Institute Russia, Elabuga

' PhD, Associate Professor, Kazan Federal University, Elabuga Institute, Russia, Elabuga

${ }^{\beta}$ PhD., Associate Professor, Kazan Federal University, Elabuga Institute, Russia, Elabuga

(C) 2020 Shastina et al. This is an Open Access article distributed under the terms of the Creative Commons Attribution License (http://creativecommons.org/licenses/by/2.0), which permits unrestricted use, distribution, and reproduction in any medium, provided the original work is properly cited.
} 


\section{Introduction}

Today the problem of reading is becoming one of the most acute in the world. In all developed countries a decline in readership has obviously resulted in the degradation of society, which is of particular concern. Reading literacy is considered as a prerequisite for successful socialisation and individual growth. The importance of this skill is reflected in the development of the International Program for assessing the academic achievements of students-The Program for International Student Assessment (PISA). In the international ranking of countries whose students have been tested for PISA, Russian indicators remain low from year to year. At the same time, according to the PIRLS (Progress in International Reading Literacy Study), which provides internationally comparative data on the progress of children from different countries in reading after four years of primary schooling, Russian students are among the best in the world. The declining interest in reading is discussed as a nationwide issue at various levels with library experts, teachers, public figures, writers, ordinary citizens, and especially parents - everybody who cares about the nation's future. The program designed to support " children's and youth reading in Russian Federation and approved by order of the Government of the Russian Federation (2017), states that the solution of this problem is" "a priority direction in the cultural and educational policy of the state, which is of paramount importance for the nation's future" (The Concept, 2017, p. 2).

Children's reading under the influence of social and cultural environment changes throughout the world, having both positive and negative effects. This situation, which leads to a decrease in the level of children's literacy, can be improved with the establishment of a mentoring institution. It will encourage teachers to read with children and strengthen the role of the family. The key purpose of this research is to probe the role of literary pedagogy in modern education of preschool and primary school children. For this, it first examines the PISA and literary pedagogy in Germany and then in Russia, the countries of which the authors of the study are respectively representatives. Following this, it reviews literature linked to PISA, literary pedagogy versus education. Then it describes the methods deployed in this study. The results are critically discussed in the sections following this.

\section{The PISA-Shock and Literary Pedagogy in Germany}

The PISA-Shock has become an idiom in Germany. It describes the effect of the first PISA study in 2000. Germany, the land of poets and thinkers reached only 484 points with an average of 500, which is far below the OECD (The Organization for Economic Cooperation and Development) countries. In the field of reading competencies, Germany ranked $21^{\text {st }}$ with 32 countries participating in the study. These results had a very chastening effect on selfconception and pride of the German education system. The German authorities had taken a range of measures: they expanded the language support, defined a special mission for kindergarteners, improved academic outcomes and attracted numerous volunteers in reading promotion. Education financing in Germany has been rising steadily since 2001, though it is still below the OECD budget. In 2015 Germany ranked 9th among 35 OECD countries participating in the last PISA study of reading competences.

However, there's much yet to be done since the results of a recent study are still quite distressing. International reading Literacy Study IGLU study on the reading competency of elementary school pupils examined 4th-grade students every five years. According to the results of the examination in 2017, $18.9 \%$ of German schoolchildren do not fully comprehend what they read. The study also showed that social background has a particularly high influence on the development of reading competences. It is noteworthy that children from families with big library collections and children whose parents are highly qualified specialists show better results in reading. 
Whenever such studies get publicity, they trigger debates in the media and become a subject of politics. Following the publication of the IGLU study results in 2017, the German children's author Kirsten Boie initiated a petition Hamburger declaration - Every child has to learn to read targeting education politicians in Germany. In two months the petition received over 70.000 signatures from authors, cultural workers and ordinary citizens. Since the end of the 20th century, the willingness to deal with literacy decline in Germany has increased significantly. Furthermore, the authorities admitted the need to consider numerous additional factors apart from developing reading skills. Today, reading literacy involves language promotion, general literacy, access to books, and the revision of digital media roles in reading socialisation. In Germany, libraries, especially for children and youth, received a new positioning under these developments. Their mission is changing from archiving and providing media to the role of a third large educational institution in addition to kindergarten and school. Children's and youth libraries not only make introductions to the library system; they also offer language support and training for parents, engage them in reading promotion. The training programs for library personnel were not prepared for this challenge. This is very much the same for volunteer reading partners. Since many people in Germany are willing to promote reading literacy among children, they also need professional guidance. Responding to this situation, ten years ago, the German authorities developed a curriculum of literary pedagogy. The training course involved approximately 360 internal teaching units and the same number of self-study stages. The Federal Association for Reading Promotion was founded almost at the same time, which is still active today. A common goal was to make literary pedagogy a recognised professional field. Today, one can see the first results of this initiative, since with advanced training librarians often receive an increase in salaries and career promotions. Freelance literary teachers are trendy at different stages of training. In University setting, literary pedagogy is currently strengthening its position. For instance, the University of Dortmund offers additional training on literary pedagogy. At the same time, the College of Applied Arts in Hamburg introduced its first course in literary pedagogy in the winter semester of 2018/19.

\section{Literature Review}

The purpose of learning in the information era has shifted from getting readymade knowledge and memorisation to its inclusion into a broader context: to develop the ability to locate, evaluate and effectively use information (Simon, 1996). Reading as a source of information, depending on the objectives, involves various reading techniques and technologies, which is both multidimensional and integrated skill.

Most early studies focus on certain aspects of the reading process. For instance, the study of reading as a complex cognitive process resulted in a theory of creative understanding, which considers behaviour-memory retrieval, analogical mapping, base-constructive analogy, and problem reformulation as prerequisites for creative reading (Moorman \& Ram, 1994).

A functional approach to reading instruction was considered in a content area. The reading strategy with the use of prepared reading guides was tested to determine the way it would influence readers' ability to recognise patterns of composition, content acquisition, social studies reading, and general reading comprehension (Vacca, 1975). Literature reading as a means of promoting critical thinking, has been the subject of several focused studies (Tung \& Chang, 2009; Johnston, 2005). It turns out that reading aloud has a qualified effect on students' vocabulary development, improves language proficiency, broadens understanding of cultural diversity, and develops critical thinking and problem-solving skills (Bozhkova et al., 2019). An effective read-aloud can enable students to learn about different types of conflicts and possible solutions as well as empathy and understanding for others.

Reader-centred critical reading was considered as a means of encouraging observation and active evaluation not only of lexical items but also of a variety of meanings and viewpoints. 
Some authors even suggested a model of teaching critical thinking skills focused on the " reader's response to a literary work (Bobkina \& Stefanova, 2015).

The concept of reading as a dual process involving emotional and cognitive spheres requires complex research. It was revealed that emotions might help to improve cognitive processes by directing readers' attention and helping them to determine the relevance of the information to the situation (Kneepkens \& Zwaan, 1994). Other literary authors proposed similar ideas (Courtland et al., 1998).

Green M. C. and Brock T. C. focus on profound changes in an individual resulting from the influence of reading - mentality changes (Green \& Brock, 2000). The transportation theory proved that fiction reading improves readers' empathy, provided that they are emotionally immersed in the story. The study proved the dependence of the reader's empathy level on his emotional transportation into the story (Bal \& Veltkamp, 2013).

A group of researchers justified a multi-factor model of literary reading to explore absorbing reading experiences. They established correlations between: a) attention as a deep concentration resulting in readers' absence from reality, b) mental imagery as mental visualisation of the story world, c) emotional engagement including feelings for or with the story's characters, such as sympathy, empathy, and identification, d) transportation as a feeling of immersion into a story world while remaining in contact with the real world, and e) enjoyment (Kuijpers et al., 2014).

Similarly scholars argued about shared and scientific reading. The study of the so-called shared reading or crowd reading of the same text by various readers, similarities and differences in text interpretation and understanding, and experience of crowd reading applied to the modelling of literary characters in computer-assisted analysis of these literary phenomena is a most promising research direction (Galleron et al., 2018).
National literature that contributes to the preservation of self-identity, development of a taste for the perception of world literature is of particular scientific interest (Bugaeva \& Sokorutova, 2018).

Considering particularities in the perception of a literary text by children, several scholars suggest updating the reader's repertoire including popular and favourite genre as the fairy tale. This refers to a modern fairy tale with values that can serve as a guide for teachers and parents (Sergeevna, 2018).

Development of the early literacy skills as a prerequisite for reading comprehension is of particular research interest (Yal Çintaetal., 2017). Early literacy is considered as an integral part of the reading literacy process (de la Rie, 2018).

Considerable empirical material in studying the problem of children's reading has been accumulated from observations of parents involved in the process of mastering primary reading skills (Bus et al., 1995).

The study of the home literacy concept presents it as a multifaceted phenomenon that includes various factors: the quality of education and the importance of cooperation between parents and children along with the social and emotional aspects. In this perspective, the study of a bilingual environment is especially promising. It was found that the influence of background factors ("parents' ethnicity and literacy) on language development and academic achievements is mediated by home literacy as well as the knowledge of the native language and early vocabulary (Leseman \& DeJong, 1998). Today, more and more is being said about the transformation of reading (Volkova, 2012), since children born to the information society are more focused on digital technologies.

In general, the e-book contributes to the development of children's reading skills. However, some studies show that the use of ebooks in family reading leads to a decrease in the quality of reading, while the quality of an e-book needs further improvement (Korat \& SegalDrori, 2016; Parish et al., 2013). The positive 
trend is that scepticism is being replaced by an awareness of the need to use all available channels of information for systematic work with children in order to revive the interest in reading.

It is common knowledge that the habit of reading is formed at an early age, therefore, it is essential that reading becomes a necessity at all stages of an individual's development. Otherwise, following the decrease in interest in reading, the overall literacy worsens, which negatively influences an individual's cultural and intellectual growth. Next section describes the methodological issues.

\section{Methods}

The methodological principles of interdisciplinary and systematic study used in modern socio-humanitarian knowledge combine theoretical research methods that allow us to expand and systematise the scientific facts about the latest trends in education. The literature review in this study is used as a qualitative method. The authors examined various statistical data for this study. They attempt to explain the effects of reading on an individual and society. A case study was intended to consolidate data from the previous studies, to evaluate the current knowledge of the problem under the study, and to outline the prospects for its solution.

\section{Discussion}

The relevance of the study is mainly because reading is the most important way of mastering scientific, professional and everyday knowledge. Reading helps an individual to accomplish basic socially significant information contained in printed and electronic books, magazines, newspapers, various documents, Internet resources. It is the most important source of social experience and knowledge accumulated by [hu]mankind (The Concept, 2017, p. 3).

The Program for children's and youth reading support notes the specificity of the reading crisis in Russia, which can be explained not \# merely by economic factors, but with a combination of factors. In the last decade, the market of children, especially pre-school literature, is experiencing a real boom. This fact might be considered an essential step towards making readership attractive. However, not everything is that simple. Naturally, the question arises of the need to develop a systematic approach to the formation and development of reading skills in a continuous educational process. In this regard, it is necessary to involve resources not only of formal but also of non-formal and informal education (Mironchuk, 2014). The authors believe that in the current conditions, the introduction of the literary pedagogy concept as an integral pedagogical process of the directed development and formation of a cultural personality by means of literature can be appropriate and must be considered in conditions of extra-university education. The use of the term literary pedagogy is also justified by the fact that in the framework of non-formal and informal education several areas of innovative educational technologies are being applied that can provide the transfer of cultural experience to the younger generation: art pedagogy, museum pedagogy, theatrical pedagogy, film pedagogy (Don, 2013; Ignatov \& Kapinova, 2018; Maslieva, 2016; Okershko, 2015; Sergeeva, 2008).

\section{Literary Pedagogy Versus Literary Education}

The term literary pedagogy is composed of two complex concepts that require clarification: literature and pedagogy. Literature is understood as a broad field of language in epic, drama and poetry, conveyed through oral narratives, books (including non-fiction), films, audiobooks and radio plays, hyperfiction, interactive games and other multimedia productions. Pedagogy is a science that deals with the theory and practice of education and its effect on the growth of learners. It explores educational and developmental contexts. However, it is also an action science, which suggests how to design and improve education and training practices.

Literary pedagogy deals with the theory and practice of literary education as well as education and development through literature. Literary education in the strict sense is a meeting and confrontation with the aesthetic field of literature in order to gain a deeper 
understanding of connections, structures and varieties. In contrast, education through literature means using literature as a tool for developing an attitude towards the world. The literature-pedagogical practice is part of an academic process that helps an individual to develop his/her capabilities. At the same time, it supports a child or an adolescent in acquiring relevant skills, such as reading or writing, which are critical for social recognition. Literary pedagogy incorporates a wide range of different sub-fields, including support in language, storytelling, reading and writing.

Literary pedagogy as a part of the academic process is designed to solve the problem of reading support from preschool age to the period of acquiring social and civic maturity. Furthermore, literary pedagogy justifies the need to develop the training of specialists, who demonstrate a willingness and ability to work in general, additional and professional education. In the nearest future, there might be introduced new majors in the relevant bachelor and master's programs, such as" editor of children's literature, media promotion specialist of 'children's literature, teacher-librarian and others (The concept, 2017, p. 13). In the logic of this study a lacuna in the list of new professions can, in our opinion, be occupied by the profession of a literary instructor designed at a qualitatively different level to coordinate the involvement of children into reading and to solve pedagogical problems using literature.

In 2016 a textbook on literary pedagogy was published in Germany (Jentgens, 2018) which consists of four sections: 1) the foundations of literary pedagogy; 2) children's and youth literature, represented in evolution (numerous varieties of literary products of various formats are represented); 3) the practical aspect of literary pedagogy for different age groups; 4) organisational forms of literary pedagogy.

For the first time literary pedagogy is considered a part of the academic process. To answer the frequently asked questions of troubled parents: My child does not want to read, what can I do to interest my child in reading? or My child has trouble, which book you could recommend to him. For this, on the one hand, one needs to have certain knowledge, on the other hand, be able to use it in a specific situation, that is, to possess a set of specific competencies allowing to successfully support a child's interest in reading, to maximise literary potential. However, the solution to this multifaceted problem goes far beyond the measures mentioned above.

A child's interest in literature begins with a sense of hearing and an understanding of what has been heard - only then does the question of reading arise. This algorithm of actions is obvious. It is only necessary to correctly balance the task of managing this process, which is one of the purposes of literary pedagogy at this age. The literature involved in the academic process becomes a means of developing a critical perception of reality. Literature is directly involved in the formation of cognitive and emotional spheres of life, developing an axiological approach to culture, etc. In this regard, it seems reasonable to distinguish between the concepts of literary education and literary pedagogy.

Literary education as a process of an individual's incorporation into the culture by means of literature is generally provided within the framework of formal education. It is subject to the normative requirements for a certain age group. The learning process ends with the award of a graduate diploma. Literary education is based on two fundamental principles - artistic and literary-aesthetic. In recent years, literary education, the problems of reading and maintaining literary education have been at the centre of the scientific interests of Russian academic teachers, along with modern strategies for teaching literature in the context of modernising Russian education; innovative technologies in literary education, etc. (Literary education, 2012). Literary education can be considered one of the crucial aspects of literary pedagogy.

\section{The Essence of Literary Pedagogy}

Literary pedagogy, as part of an integrated system of continuing education, should be considered in the context of innovative activities 
to support children, youth and family reading. The essence of literary pedagogy should focus on the solution of the following tasks:

- scientific and methodological work on problems associated with improving the reading culture of an individual and society as a whole;

- support of children's literature, book publishing and book distribution;

- development of infrastructure for children, youth and family reading;

- development of human resources;

- activities in the media promoting children's and youth reading.

Two questions are essential for the qualification of literature pedagogues: What is the goal of qualification and what knowledge and skills should be promoted? The aim is to promote personal and social skills as well as knowledge and methodological competence. Professionals should be enabled to:

- develop projects in the field of literacy and reading promotion;

- identify the level of child's reading competences and language skills;

- select and evaluate offers for the target audience;

- independently develop audienceoriented methods of mediation;

- develop concepts;

- advise parents or volunteers in the field of reading promotion;

- create a profile for their own offers.

To do this, the basics need to be taught in the areas of:

- theory and history of children's and youth literature;

- overview of the current children's and youth market;

- teaching methods of children's and youth literature;

- reading aloud, storytelling and creative writing;

- presentation techniques;

- pedagogy and developmental psychology;
- artistic forms of expression (e.g. visual arts, theatre, music);

- planning, organisation and event management;

- knowledge of the relevant institutions and networks;

- methods for structured self-reflection and collegial advice.

\section{Conclusion}

Reading is a complex phenomenon requiring interdisciplinary research. Numerous studies provide grounds for concluding the integrative nature of reading skills. Even though numerous scientific articles and monographs have been published on this subject, the problem is still debatable. This is because the reasons for the change in the cultural vector, in which reading loses its importance as a cultural source and loses its dominant position to the Internet with its unlimited resources, require further examination.

A study of literary sources on the problem of teaching reading, accumulated information on the goals and patterns of the reading process as a synthetic phenomenon, its impact on social, psychological, cognitive, aesthetic and other aspects of the personality leads to a logical conclusion - there is an urgent need (and possibility) of establishing a certain system in the theory of learning and development of specialists in the field of literary pedagogy.

\section{References}

Bal, P.M., \& Veltkamp, M. (2013). How Does

Fiction Reading Influence Empathy? An

Experimental Investigation on the Role of Emotional Transportation. PLOS ONE, 8(1), e55341.

https://doi.org/10.1371/journal.pone.0055341 DOI:10.1371/journal.pone.0055341

Bernice, E.C. (2000). Independent Reading and School Achievement. School library media research. Research journal of the American association of school librarians, vol. 3. Retrieved on 12 September 2018 from, https://docplayer.net/81390-Independentreading-and-school-achievement.html 
Bobkina, J., \& Stefanova, S. (2016). Literature and critical literacy pedagogy in the EFL

classroom: Towards a model of teaching critical thinking skills. Studies in Second Language Learning and Teaching. SSLLT, 6(4), 677-696. DOI:10.14746/ssllt.2016.6.4.6Corpus ID: 55717684

Borsheim-Black, C., Macaluso, M., \& Petrone, R. (2014). Critical Literature Pedagogy. Journal of Adolescent \& Adult Literacy, 58(2), 123-133. DOI: 10.1002/jaal.323

Bozhkova, G. N., Shastina, E. M., Kalimullina, O. V., \& Shatunova, O. V. (2019). Study of literary images of gifted characters in optional activities as a means to develop capable and talented youth. Space and Culture, India, 7(1), 264-273. doi:10.20896/saci.v7i1.463

Bugaeva, A.P., \& Sokorutova, L.V. (2018). Influence of Children's Yakut literature on the Development of the Spiritual and Moral Culture of Younger Schoolchildren. Perspektivy Nauki i Obrazovania, 34 (4), 189-194. Bus, A.G., Van IJzendoorn, M.H., \& Pellegrini, A.D. (1995). Joint Book Reading Makes for Success in Learning to Read: A Meta-Analysis on Intergenerational Transmission of Literacy. Review of Educational Research, 65 (1),1-21. DOI: $10.2307 / 1170476$

Courtland, M.C., French, M.E., Owston, S., \& Stead, V. (1998). Literary text, the reader, and the power of shared response. Canadian Journal of Education, 23(3), 329-34. DOI: 10.1179/152991005791330195

Sanneke de la Rie, Roel C.M., van Steensel, R.C.M., van Gelderen, A.J.S., \& Severiens, S. (2018). The role of type of activity in parentchild interactions within a family literacy programme: comparing prompting boards and shared reading. Early Child Development and Care, 188 (8), 1076-1092. doi: 10.1080 / 03004430.2016 .1248957

Désiron, J.C., Vries, E., Bartel, A.N., \& Varahamurti, N. (2018). The influence of text cohesion and picture detail on young readers' knowledge of science topics. British Journal of Educational Psychology, 88( 3), 465-479. DOI:10.1111/bjep.12195Corpus ID: 19273628 Desmond, R. The Role of Reading for Children and Adolescents in a Digital Age, Retrieved on 4 October 2018 from,

https://us.sagepub.com/sites/default/files/upm binaries/41872_Singer_2e_Rev_Final_Proof_\%2 $8 \mathrm{ch} \_2 \% 29 . p d f$

Don, T.K. (2013). Art Pedagogy in the Modern Educational Paradigm. Science. Art. Culture, 2, 144-152.

Fyfe, P. (2011). Digital Pedagogy

Unplugged. Digital Humanities Quarterly, vol. 5, no. 3. Retrieved on 4 October 2018 from, http://digitalhumanities.org/dhq/vol/5/3/0001 06/000106.html

Galleron, I., Idmhand, F., \& Meynard, C. (2018). Let a thousand readings flourish. $A$ crowdreading experience. Digital humanities quarterly, 12, (1.) Retrieved on insert date and year from, http://www.digitalhumanities.org/dhq/vol/12/ 1/000363/000363.html DOI:10.1037/0022-3514.79.5.701Corpus ID: 10197772

Geske, A., \& Ozola, A. (2008). Factors influencing reading literacy at the primary school level. Problems of education in the $21^{\text {st }}$ century, vol. 6, pp. 71-77.

Gorshkova, V.V. (2014). Interaction of formal, non-formal and informal education as a modern trend in human development. Concept. Retrieved on 4 October 2018 from, http://ekoncept.ru/2014/64336.htm.

Green, M. C., \& Brock, T. C. (2000). The role of transportation in the persuasiveness of public narratives. Journal of Personality and Social Psychology, 79(5), 701-721.

DOI:10.1037/0022-3514.79.5.701Corpus ID: 10197772

Ignatov, D.M., \& Kapinova, E.S. (2018). Kinopedagogika as an interactive method of teaching methods of physical education in primary school. Prospects of science and education, 2(32),215-218. ISSN 2307-2334

Jentgens, S. (2016). Lehrbuch Literatur pädagogik. Eine Einführung in Theorie und Praxis der Literatur vermittlung. Beltz Verlag, Weinheim Basel, $244 \mathrm{~s}$. Retrieved on 3 November 2018 from, 
https://www.beltz.de/fileadmin/beltz/leseprob en/978-3-7799-3330-4.pdf. ISBN:978-3-77993330-4

Johnston, V. (2015). The Power of the Read Aloud in the Age of the Common Core. The Open Communication Journal, no. 9, pp. 34-38. DOI:10.2174/1874916x01509010034Corpus ID: 145112952

Kamil, M. L. (2003). Reading for the 21st century: Adolescent literature teaching and learning strategies. Alliance for Excellent Education. Available at:

http://www.adlit.org/article/19422/ (Accessed 20 September 2018).

Kneepkens, E.W.E.M., \& Zwaan, R.A. (1994). Emotions and literary text comprehension. Poetics 23, 125-138. DOI:10.1016/0304422X(94)00021-W

Korat, O., \& Segal-Drori, O. (2016). E-Book and Printed Book Reading in Different Contexts as Emergent Literacy Facilitator. Early Education and Development, 27(4), 532-550, DOI:10.1080/10409289.2016.1095613 Kuijpers, M.M., Hakemulder, F., Tanb, E.S., \& Doicarub, M.M. (2014). Exploring absorbing reading experiences. Developing and validating a self-report scale to measure story world absorption. Scientific Study of Literature, 4(. 1), 89-122. DOI:10.1075/ssol.4.1.05kui

Leseman, P.P.M., \& De Jong, P.F. (1998). Home literacy: Opportunity, instruction, cooperation and social-emotional quality predicting early reading achievement. Reading Research Quarterly, 33 (3), 294-318.

doi:10.1598/rrq.33.3.3

Linnakylä, P, Malin, A., \& Taube, K. (2004). Factors behind Low Reading Literacy Achievement. Scandinavian Journal of Educational Research, 48 (3), 231-249. DOI:10.1080/00313830410001695718

Literary education in the modern world: problems and solutions (2012). XX Golubkov Readings: Proceedings of the International Scientific and Practical Conference, March 1516, Moscow: Ekoninform, , 174 p.

Mar, R.A., Oatley, K., \& Peterson, J. B. (2009). Exploring the link between reading fiction and empathy: Ruling out individual differences and examining outcomes. Communications, 34,407428. DOI:10.1515/COMM.2009.025

Maslieva, E.S. (2016). The system of principles of teaching a foreign language on the basis of pedagogy. Successes of modern science and education, 2 (12), 159-163.

Mironchuk, E.V. (2014). Interdisciplinary connection of the pedagogy of the school and theatrical pedagogy in the process of training professionally competent students of the pedagogical university. Bulletin of Moscow State Regional University. Series: Pedagogy, 4 4185-190.

Moorman, K., \& Ram, A. (1994). A functional theory of creative reading. Retrieved on 10 October 2018 from, at: https://pdfs.semanticscholar.org/e978/877b9fd eb5fefe104940f143b174e7a2faa9.pdf. DOI:10.21236/ada496794

Morrow, L. M. (1983). Home and school correlates of early interest in literature. Journal of Educational Research, 76, 221-230, DOI:10.1080/00220671.1983.10885455 Nipold, M., Duthie, J., \& Larson, J. (2005). Literacy as a leisure activity: Free-time preferences of older children and young adolescents. Language, speech, and hearing services in schools, 36(2), 93-102. DOI: 10.1044/0161-1461(2005/009)

Okershko, A.V. (2015). Informational education in the Context of Globalization // Problems and Prospects of Humanities in the Context of Globalization: Proceedings of the VII International Scientific and Practical Conference (] 2015, Moscow). Moscow: Perot, 77-81.

Parish-Morris, J., Mahajan, N., Hirsh-Pasek, K., Golinkoff, R.M., \& Collins, M.F. (2013). Once upon a time: Parent-child dialogue and storybook reading in the electronic era. Mind, Brain, and Education, 7 (3), 200-211. DOI:10.1111/mbe.12028

Senechal, M., \& Le Fevre, J. (2002). Parental involvement in the development of children's reading skill: A 5-year longitudinal study. Child Development, 73(2),445-460.

DOI:10.1111/1467-8624.00417 
Sergeeva, N.Yu. (2008). The content of the concept of "art pedagogy". Izvestia VSPU,. 1, 23-28.

Sergeevna, G.M. (2018). The modern fairy tale as a means of development of speech of preschool children and education of reader's interests. Perspektivy Nauki I Obrazovania, 33 (3), 211-216.

Shekhovskaya, N.L., \& Mandeebura, E.P. (2011). Museum pedagogy: historical and pedagogical analysis. Scientific bulletins of Belgorod State University. Series: The humanities, 101,343-350.

Simon, H.A. (1996). Observations on the sciences of science learning, Paper prepared for the Committee on Developments in the Science of Learning for the Sciences of Science Learning: An Interdisciplinary Discussion. Retrieved on 14 September 2018

from,https://learnercenteredteaching.wordpres s.com/articles-and-bo s/the-learner-centeredclassroom/ DOI: 10.1016/S01933973(99)00055-6

Smart, D., Youssef, G.J., Sanson, A., Prior, M., Toumbourou, J.W., \& Olsson, C.A. (2017). Consequences of childhood reading difficulties and behaviour problems for educational achievement and employment in early adulthood. British Journal of Educational Psychology, 87(2), 288-308.

DOI:10.1111/bjep.12150

The Concept of the program to support children's and youthreading in Russian Federation. Approved by the decree of the
Government of the Russian Federation on June 3, 2017, no. 1155-r, 15 p. Retrieved on 4

October 2018

from,:http://static.government.ru/media/files/ Qx1KuzCtzwmqEuy70A5XIdAz9LMukDyQ.pdf

Tung, C., \& Chang, S. (2009). Developing critical thinking through literature reading. Feng Chia Journal of Humanities and Social Sciences, 19, = 287-317.

Vacca, R.T. (1975). The development of a functional reading strategy: Implications for content area instruction. The Journal of Educational Research, 69(3,) 108-112. Retrieved on 4 October 2018 from, https://www.jstor.org/stable/27536841?seq=1 \#page_scan_tab_contents.

Volkova, E.A. (2012). Transformation of college student's reading: the end of 80th. XX - the beginning of XXI centuries. Cand.Ped. Sci. Diss.. Krasnodar, 174

Weber, C., \& Cavanaugh, T. (2006). Promoting reading: Using eBooks with gifted and advanced readers. Gifted Child Today, 29(4), 56-63. DOI: 10.4219/gct-2006-9

Yal Çinta Ş Sezgin, \& E., Ulus, L. (2017). The early literacy at preschool education: The book or the E-book? Turkish Online Journal of Educational Technology, 16 (4), 77-83.

Zakharov, A.B., \& Kapuza, A.V. (2017). Parenting practices for learning to read and the level of reading literacy of children in Russia: According to PIRLS-2011. Issues of Education, 2, 234- 257. 